\title{
Doing Stylistic Versus Critical Stylistic: An Analysis of If by Rudyard Kipling
}

\author{
Suadad Fadhil Kadhum Al-Janabi \\ Department of English Language, College of Languages \\ University of Baghdad, Baghdad, Iraq \\ Correspondent soadod.kadhem@colang.uobaghdad.edu.iq \\ Nawar Hussein Rdhaiwi Al-Marsumi \\ Department of English Language, College of Languages \\ University of Baghdad, Baghdad, Iraq
}

Received: 9/27/2020

Accepted: 2/4/2021

Published: $3 / 24 / 2021$

\begin{abstract}
This paper displays the ideological positioning as found in Rudyard Kipling's poem If. It is a poem published in 1910. It presents the embedded ideologies and shows how the poet used the available linguistic resources to achieve his goal. The models of analysis adopted are Critical Stylistics as proposed by Lesley Jeffries (2010) and Stylistic Analysis as submitted by McIntyre (2010). The paper aims at identifying the poet's beliefs to show that success is the outcome of self-control and a real sense of the values of things. It is a try to discover how the poet used various linguistic choices to build a message telling us how to deal with life confidently and identify a line of ideological positioning through Critical Stylistic strategies. The paper presents a theoretical background of the term stylistics and critical stylistics, explaining the adopted models; Analyzing the poem stylistically with a focus on critical stylistic regarding two tools: Representing and Negating for their dominant use in the poem and their effectiveness in interpreting the hidden ideologies. Stylistic devices are used because they steer the text to enable the writer to reach the intended goal. In conclusion, the paper displays that the poet uses the stylistic tools in a brilliant way that leads All, not only his son, to follow and consider it a moral lesson of life.

Keywords: critical stylistic analysis, stylistics, Rudyard Kipling poem If, material actions, mental processes, verbalization

Cite as: Al-Janabi, S.F.K., \& Al-Marsumi , R.H.R.(2021). Doing Stylistic Versus Critical

Stylistic: An Analysis of If by Rudyard Kipling. Arab World English Journal, 12 (1) 239-252.

DOI: https://dx.doi.org/10.24093/awej/vol12no1.17
\end{abstract}




\section{Introduction}

Every time a language is used, the writer or the speaker needs to adopt a particular style. Language is considered a fundamental tool for communication that can effectively achieve specific goals to reach the desired influence. The user of the language can select from a series of stylistic possibilities according to the aim of the speech, poem, essay, etc. The poem gains its impact from the specific style which the poet uses to deliver what he/she wants to convey since stylistics is concerned with exploring language and specifically exploring creativity in language use. Accordingly, stylistics has its principal aim to observe the prospective expressive energies in a language, not in a person.

Selecting specific stylistic devices to convey a message is powerfully manifested in literary works and, most specifically, in literature. The didactic poem If has a special privilege over all kinds of poetry for its veracity. It reflects proof of dignified morals. This kind of poetry is the most genuine and authentic sort of poetry because it comes from the human soul depths and mind. The poet tries to express his feelings or give entertainment and teach or give instructions about a specific case. Thus, this study explores the language of didactic poetry in English stylistically at two levels: negation and representation. It displays and identifies the poet beliefs to make it clear that success results from self-control and a real sense of things' values. It manifests how the poet used various linguistic choices to build a message of life.

\section{Literature Review Style and Stylistics}

Style is a choice of linguistic means. Every writer makes choices to put things of expression, and there in the choices, the style resides. Supporting this idea, style is viewed by Haynes (2006) as "a matter of the careful choice of exactly the right word phrase, le mot juste"(p. 2). Verdonk 2002 stated that language style could also be "a set of conscious or unconscious choices of expression, inspired or included by a particular context" (p. 3). Abrams (1999) displayed style to show how writers and speakers used certain linguistic expressions to convey whatever they want to say. All the definitions of style can cover the term stylistics. Thus, the most common definition of stylistics, found in dictionaries, is 'the study of style.' However, according to Spencer (1998), stylistics signifies exploiting linguistics as a tool for literary criticism to search and inspect the aesthetic effect of language in a broad sense and style in a specific sense.

Nevertheless, this view is somehow vague and challenged. Simpson (2004) states that stylistics is "a method of textual interpretation in which primacy of place is assigned to language" (p. 2). Whereas, Scott (2013) mentions that stylistics is an academic discipline between language and literary studies. It investigates the readers' interactive behavior with the style of texts to show how the text is understood and how the readers are affected by the texts when they read them. Verdonk (2002) states that stylistics is "the analysis of distinctive expressions in language and the description of their purposes and effects" (p. 3). In conclusion, stylistics aims to study the style of language usage in different contexts, either linguistic or situational, and to provide a detailed description of the work in question. 


\section{Critical Stylistics}

Critical stylistics is a term that refers to the stylistic activity used in the methods in which social meanings are verified through language. This stylistic tendency is conducted by critical linguistics and CD (Norgaard, Busse, \& Montoro, 2010). Critical Stylistics is assigned to Lesley Jeffries' work, which is based on work in CDA, which uses different analysis methods to display the link between language, power, and ideology (Evans \& Schuller, 2015). Moreover, the term Critical Stylistics was first used by Jeffries (2007). Critical stylistics sets the objective of combining the powers and advantages of stylistics and CDA to show the way writers insert their ideologies with the other social concepts into their writing. Coffey (2013) pinpoints that Critical Stylistics attempts to connect CDA and stylistics. CDA is applied to show how language is involved in social relations of power and domination. Stylistics, which is 'the study of style,' deals with analyzing 'literary language' to display the connection between language and artistic fiction.

Jeffries (2010) shows that Critical Stylistics is used to "assemble the main general function that a text has in representing realities" (p. 14). She adds that Critical Stylistics provides several tools, which are assumed to be more comprehensive than any other work in CDA. Lesley Jeffries published her book Critical Stylistics in 2010, integrating CDA and stylistics with a particular emphasis, as Dopar (2015) states, on the actual linguistic manifestation of social meaning and the needed analysis tools, which is called textual conceptual functions. Moreover, Jeffries (2010) asserts that 'textual conceptual functions' are used to display the implicit ideologies produced by linguistic choices.

Critical statisticians utilize the linguistic features that are described in many semanticgrammatical theories and models as analytical tools, as Jeffries (2010) shows "for the different methods in which texts allow/ ask us to conceptualize the topics they are addressing and to provide some means of accessing this representational practice" (p. 14).

\section{Differences between Critical Stylistics and Critical Discourse Analysis}

CDA lacks a comprehensive, complete account of tools for the analyst to utilize. In contrast, critical stylistics, in turn, has a systemic analytical model that incorporates tools from stylistics and critical linguistics to display "linguistic choices of text producers and their possible ideological motifs and implications" (Coffey, 2013, p. 30).

Jeffries (2010) asserts that Critical Linguistics and CDA do not present an analysis framework that shows the texts' hidden ideologies. Therefore, she offers ten analytical tools to examine textual ideology. These tools resemble the eclectic model of tools that were created by scholars as Fowler (1991), Simpson (1993), and Fairclough (1989).

Critical stylistics deals with uncovering the texts' underlying ideology manifesting how language is used to apply particular ideologies through literary or non-literary texts without considering the outside circumstances (Jeffries, 2014). CDA deals with the social, historical, visual texts putting the external circumstances at the core of the analysis. Jeffries realizes that stylistics analysis is being useful and insightful in the same way when the data was non-fiction and when literary. (Jeffries, 2014) 
Critical stylistics shows that all texts are ideologically influenced consciously or unconsciously (Olaluwoye, 2015). It offers a set of analytical tools that help the analyst shed light on the texts' hidden ideologies in an objective way.

Jeffries (2016) coincides with Fowler's (1966) definition of ideology as she put up with that ideology is prevalent in texts and reflects the principles of credibility in a particular community or group. Besides, Jeffries (2010) defines ideology as "those ideas that are shared by a community or society [...] are an essential aspect of the world that we live in, and they are, of course, communicated, reproduced, constructed and negotiated through language" (p.5).

\section{Methods}

\section{The Adopted Models}

Rudyard Kipling If is the title of the poem under analysis. Rudyard Kipling was born in 1865 in India. He was John Lockwood Kipling's bright son, who is a teacher of English art. His mother was Scottish. Kipling spent the best six years of his early life in India. In 1871 his mother sent him to England, where he lived with a foster family. This situation, which makes him live a complicated life, has a significant impact on him, and could not hinder his innovation. His poem "if" is a didactic poem. It delivers a life lesson. The poet, who is the speaker in this poem, gives his son instructions concerning whatever he can do and can not do overtime to be a man. It is considered a lesson about crucial things in life. He teaches his son the matters in life that worth fighting for. He teaches his son how to be self-controlled and how to become a winner. It is a lesson not only to his son but a lesson to ALL through his son.

The models adopted for analysis are: Firstly, The stylistic analysis model as proposed by McIntyre (2010); Secondly, the analytical model proposed by Jeffries (2010) which consists of ten tools and I chose two tools to be adopted which are: Representing( Actions /Events/States) and Negating for their dominant use in the poem and their effectiveness in interpreting the hidden ideologies.

\section{McIntyre's Model (2010)}

In his article, McIntyre (2010) demonstrates that stylistics aims to illuminate how the words of specific text generate the feelings and responses that the reader gets from these selected words when reading them. His model of analysis is based on some procedures. The procedures adopted by McIntyre (2010) are as follows: 1. Looking at the chosen poem. This step gives a general description of the poem. It focuses on the striking irregularities of forms like lack of capitalization, the strange use of punctuation, and the odd structure of particular phrases. 2. Examining the lexical features. In this step, McIntyre concentrates on the open class words showing how they are distributed throughout the poem and whether they are nouns, verbs, adjectives, or adverbs. 3. Breaking down the open classes into some essential semantic areas. In this step, each part of speech within the semantic areas are to be examined according to their numbers to understand the reasons behind the differences between them. 4. Pointing out the unusual word and the neologism. 5. Studying the existence of the foregrounded aspects in the repetition, deviation, and parallelism. 


\section{Jeffries's Model (2010)}

The following is a survey of the tenth tools that Jeffries' model has:

\section{Naming and Describing}

Naming indicates the choices of a noun that may be used to denote the same entity. It can be done directly by choosing nouns from the available alternates, using certain modifications to describe that referent within the noun phrase domain, and using nominalization in specific contexts that can be expressed using verbs. The above mentioned are essential methods that can invent ideological meaning in the text.

\section{Representing Actions/Events/States}

Jeffries (2010) uses this tool to display how the speaker or writer expresses the event in terms of actions, events, and states. It deals with the noun phrase semantic function according to the verbal elements.

\section{Equating and Contrasting}

This tool's debate is that all texts can create new synonyms and antonyms between words, phrases or clauses, or the whole paragraphs. It concerns with how the world is structured in the texts in terms of both equation and opposition. The semantic relations that are textually constructed refer to similarities and differences of meaning.

\section{Exemplifying and Enumerating}

The choice of using exemplification or enumeration in specific text relies on pragmatic inferencing. It is used to decide which one is more relevant than the other in a given case. This case happens because there is no linguistic difference in functions between them.

\section{Prioritizing}

The syntactic opportunities of prioritizing certain information over the other rely on the fact that while structuring the sentence of the language, in specific structures, we put the essential information at the beginning as in fronting through the transformational process and in other structure we put the prioritizing information in the final position as insubordination as the main obligatory clause bears the most critical information.

\section{Implying and Assuming}

This tool is mainly concerned with pragmatics as the latter deals with the implicitly in the language. The utilization of assumptions and implications to give common sense to the ideologies is called naturalization. It is a method of vital importance that can influence people's viewpoints.

\section{Negating}

It is used In a general term to deal with the conceptual practice rather than the verb negative form. It helps the speaker produce a hypothetical version of reality. It has the power of a persuasive kind. It can be a negative power or a positive one. Such constructions create implicatures about the other realities that may occur by disregarding the Gricean maxim of quantity. 


\section{Hypothesizing}

The hypothetical reality in the text can be manifested by using modality. Halliday (1994) believes that the language's interpersonal metafunctions can be expressed by using the modal system. However, Jeffries assumes that modality is ideational according to the conceptual meaning that it has. It can show the different ways of influence on the reader or hearer (Jeffries, 2016).

\section{Presenting Others' Speech and Thought}

This tool presented others' words and thought through direct and indirect speech and according to the textual function (Jeffries, 2016).

\section{Representing Time, Space and Society}

It shows the moment, place, audience, and context of the text displayed through the linguistic realization. The use of deixis within the text becomes more sensitive to textual ideology (Jeffries, 2016).

\section{Stylistic Analysis}

\section{Looking at the Chosen Poem}

Using stylistic tools to analyze particular text doesn't resemble a literary analysis. Literary analysis is less objective and rooted than stylistic analysis. Stylistic analysis displays how the chosen linguistic elements construct the intended semantic goal to get the readers' desired reactions. The poem If is typical of Rudyard's style. It consists of 30 lines. For example, one notices the excessive use of If clause with no independent (main) clause as if it reflects one sentence length. The independent clause appears at the end of the poem, in the last two lines. The poem is full of instructions in the form of conditions full of negative and imperative forms. The poet uses such constructions to steer the readers' intention to read the whole poem to see if he/she fulfills all these conditions, what will happen. If at the beginning of sequential sentences is to stir emotion and unify separate sentences into a cohesive whole.

\section{Examining the lexical Categories}

McIntyre 2010 concentrates on the open class words showing how they are distributed throughout the poem within the limit of their major categories.

Table 1. Distribution of open class words ( Content Words) in the poem If

\begin{tabular}{|l|l|l|l|}
\hline Nouns (line No.) & Verbs (line No.) & Adverbs & Adjectives (line No.) \\
\hline Men (3) & Keep your head (1) & & Tired (5) \\
\hline Allowance (4) & Losing, Blaming (2) & & Good, wise (8) \\
\hline doubting (4) & Trust, Doubt (3) & & worn-out(16) \\
\hline Lies (6) & Make (4) & & \\
\hline Hating(7) & Wait, Waiting (5) & & \\
\hline Dreams, master (8) & Lied, Deal (6) & & \\
\hline Thoughts, aim(10) & Hated, give (7) & & \\
\hline Aim (10) & Look, talk (8) & \\
\hline Triumph, disaster (11) & Dream, make (9) & & \\
\hline Impostors(12) & Think, make(10) & \multicolumn{2}{|c|}{ www.awej.org } \\
\hline \hline
\end{tabular}

ISSN: 2229-9327 
Arab World English Journal (AWEJ) Volume 12. Number 1. March 2021

Doing Stylistic Versus Critical Stylistic: An Analysis of If

Al-Janabi \& Al-Marsumi

\begin{tabular}{|l|l|l|l|}
\hline Truth(13) & Meet (11) & & \\
\hline Knaves, trap, fools(14) & Treat(12) & & \\
\hline Things, life (15) & Bear, hear (13) & & \\
\hline Tools(16) & Twisted, make (14) & & \\
\hline Heap, winnings (17) & Watch, gave, broken(15) & & \\
\hline Turn, pitch, toss (18) & Stoop, build (16) & & \\
\hline Beginnings(19) & Make(17) & & \\
\hline Word, loss(20) & Risk (18) & & \\
\hline Heart, nerve,sinew(21) & Lose, start (19) & & \\
\hline Turn(22) & Breathe (20) & & \\
\hline Will (24) & Force(21) & & \\
\hline Crowds, virtue(25) & Serve, gone (22) & & \\
\hline King, touch(26) & Hold on (23) & & \\
\hline Foes, loving, friends (27) & Says, hold on(24) & & \\
\hline Men(28) & Talk, keep (25) & & \\
\hline Earth(29) & Walk, lose(26) & & \\
\hline Man, son (30) & Hurt (27) & & \\
\hline & Count (28) & & \\
\hline & Be (30) & & \\
\hline 44 & 47 & 0 & 4 \\
\hline $46.315 \%$ & $49.473 \%$ & $0 \%$ & 4.210 \\
\hline
\end{tabular}

The total number of content words used in the poem is (95). The high number (47) and the frequency rate $(49.473 \%)$ of verbs indicate that the poem or the poem's instructions need actions that are strictly required to achieve the triumph. The number of nouns (44) and the frequency rate (46.315) seem to be close to rate of the verbs used in the poems. Such a rate of nouns indicates that the poem is an excellent example of stability.

There is no adverb mentioned in the poem, which indicates that this is a real lesson for ALL without considering the place or time. It is a lesson of how to grow up and become a man no matter where or when the given instructions should be fulfilled. Only four adjectives are used with a rate of (4.210). This rate indicates that the poem is not a descriptive one.

Breaking down the Open Classes into some Basic Semantic Areas

Table 2. A Breakdown of nouns in the poem

\begin{tabular}{|c|c|c|c|c|c|}
\hline \multicolumn{2}{|c|}{ Total } & Concrete nouns & Abstract nouns & $\begin{array}{c}\text { Nouns indicate } \\
\text { triumph }\end{array}$ & $\begin{array}{c}\text { Nouns indicate } \\
\text { disasters }\end{array}$ \\
\hline Number & 44 & 20 & 24 & 16 & 12 \\
\hline$\%$ & 100 & 45.454 & 54.545 & 36.363 & 27.272 \\
\hline
\end{tabular}

Nouns in the selected poem are analyzed within five rough areas of the semantic field. Concrete and abstract nouns are (20) and (24) respectively, and with frequency rates of (45.454) and (54.545) respectively are distributed in the poem. The relatively similar rate of both nouns refers to the everlasting relation between concrete or material and what is abstract or untouchable in humans' lives. The numbers of nouns that refer to triumph, disasters and that are neutral as for 
Arab World English Journal (AWEJ) Volume 12. Number 1. March 2021

the theme of triumph and disasters (16), (12) and (16) respectively and with frequency rates of (36.363), (27.272), and (36.363) respectively are distributed in the poem in such a way that shows how the theme of triumph and disaster affects the poet's inspiration to draw the lines of instructions.

Table 3. A breakdown of verbs in the poem

\begin{tabular}{|l|l|l|}
\hline Semantic areas & No. & $\%$ \\
\hline Total verbs & 47 & 100 \\
\hline Transitive verbs & 31 & 65.957 \\
\hline Intransitive verbs & 16 & 34.042 \\
\hline Stative verbs & 16 & 34.042 \\
\hline Dynamic verbs & 31 & 65.957 \\
\hline Verbs with a human agent & 46 & 97.872 \\
\hline Verbs with a non-human agent & 1 & 2.127 \\
\hline Passive voice & 1 & 2.127 \\
\hline Active voice & 46 & 97.872 \\
\hline
\end{tabular}

Rudyard Kipling uses transitive verbs (31) times with a frequency rate of $(65.957 \%)$ while there are only (16) intransitive verbs that show the frequency rate of $(34.042 \%)$. He uses verbs like lose, trust, give, keep, hurt, count, say, etc. This displays that the poet is stable to incorporate all the details that can be achieved by using these verbs. The highest number and frequency rate of dynamic verbs over stative verbs is (31) times with a frequency rate of (65.957\%), which is a typical result of the continuous actions that the poet asks (YOU) to fulfill to be successful mankind. Only one passive verb and all others are active, i.e., $97.872 \%$ are active to express Rudyard Kipling's desire to make the doer of his verbs clear.

Table 4. A Breakdown of adjectives in the poem

\begin{tabular}{|l|l|l|}
\hline Semantic areas & No. & $\%$ \\
\hline Total adjectives & 4 & 100 \\
\hline Predicative adjective & 3 & 75 \\
\hline Attributive adjective & 1 & 25 \\
\hline
\end{tabular}

Because the poem is not a descriptive one, the poet uses very few adjectives, but out of four adjectives, $75 \%$ are predicative adjectives. Such adjectives modify the subject, who is the doer of the action, and the whole poem.

\section{Pointing out the Unusual Word and the Neologism}

All words that are used by the Rudyard are ordinary words which can be roughly divided into some semantic fields; triumph, disaster, and characters. From the field of triumph come the words winnings, triumph, trust yourself, look good, and virtue. From the disaster field come the words; disaster, trap, pitch, toss, loss, lies, hating, and hurt. From the characters' field come the words; men, masters, imposters, knaves, king, friends, and son.

\section{Studying the Existence of the Foregrounded Aspects in the Repetition, Parallelism, and Deviation}

Table 5. Instances of foregrounding in If

\begin{tabular}{|c|c|c|c|c|c|c|}
\hline \multicolumn{2}{|c|}{ Total } & \multicolumn{2}{c|}{ Repetition } & \multicolumn{2}{c|}{ Parallelism } & \multicolumn{2}{c|}{ Deviation } \\
\hline No. & $\%$ & No. & $\%$ & No. & $\%$ & No. \\
\hline
\end{tabular}


Arab World English Journal (AWEJ) Volume 12. Number 1. March 2021

Al-Janabi \& Al-Marsumi

91 100 70 76.923 11 12.087 10 10.989

Repetition takes the highest rate with its total number of (70) instances. The poet intentionally repeats the pronoun "you" (18) times and "if" (14) times to express the conditions that "YOU" must follow to be a Man. The auxiliary verb" can" is repeated (10) times. The pronoun "your" is repeated (9) times. The negative particle "not" is repeated (6) times. The verb "make" is repeated (4) times. The relative pronoun "when" is repeated (3) times. The words "dream," "hate," and "hold on" are repeated (2) times equally. Rudyard uses parallelism throughout the poem several times as he uses the construction "If you can..."(11) times to show suspense concerning the conditions that bear the spirit of advice. He intentionally delays the response to the condition till the end of the poem, as the poet displays the consequences that come up after fulfilling these conditions. Besides, such parallelism adds a rhythmical feeling to the poem. All instances of deviation are ( 10 ) with their frequency rate ( 10.989 ). Within the area of semantic deviation comes Personification; as seen in the poem, this kind of figure of speech can be seen in 4 places. In the second stanza, the poet personifies "dreams" to be just like "masters" who can control our lives. Besides, in the second stanza, too, Rudyard personifies "success" as " triumph" and "failure" as "Disaster." In the third stanza, Rudyard personifies" will" as a person; Metaphor: In the first stanza, Rudyard uses "impostors" to refer to "triumph and disaster." And "worn-out tools" is used in the third stanza to refer to feeling; and Symbolism: The poet uses some words to symbolize people such as "knaves" is used to represent "liars"; " crowds" indicates "people"; "kings" refers to significant people, and "common touch" stands for humility.

\section{Critical Stylistic Analysis}

\section{Representing Actions/Events/States}

It considers the textual- conceptual function that signifies the choice of transitivity. It demonstrates the noun phrase semantic function regarding verbal elements. It shows how the situation is expressed by the writer or the speaker according to events, states, or actions and who bears the responsibility for the resulted action (Jeffnes, 2016). His tool refers to Halliday's (1985) and Simpson's Model (1993), which is based on Halliday's work. The model is used to describe predicators' choices in a particular text and its effects. It concerns the meaning level associated with the verbal clause part and submits information on the action, event, and states. Jeffries (2010) displays the transitivity model categorization:

1- Material Action Processes represent the main category. They are the processes of doing in the physical world. It involves two participants. One of them is the actor, who is the doer of the action. It is an obligatory participant. The second participant is the goal, which is an optional participant. It expresses the person or entity, whether animate or inanimate, affected by the process. The subcategories reflects Intention, Supervention, Event (Simpson,1993).

2- Verbalization Processes represent the main category. They are the processes of "saying" covers any kind of symbolic exchange of meaning. A verbal process contains three participants: Sayer, Verbiage, and Receiver. Te Sayer is the participant responsible for the verbal process. The Verbiage is a normalized statement of the verbal process. The Receiver is the one to whom the verbal process is directed (Eggins, 2004). This type of process includes verbs like tell, promise, suggest, announce, inform, etc. 
Arab World English Journal (AWEJ) Volume 12. Number 1. March 2021

3- Mental Cognition Process is called the process of sensing. It is the process of feeling, thinking, and receiving. Simpson (1993) labels this process as an internalized process compared to the externalized processes of doing and speaking. The mental process involves two participants: the sensor and the phenomenon. The sensor reflects the conscious being that is feeling, thinking, or seeing. The phenomenon demonstrates what is sensed- felt, thought, or seen (Eggins, 1994; Halliday,1985).

Mental process verbs are subcategorized by Halliday (1994) into three types: Cognition, Affection, and Perception. Cognition can be manifested through verbs of thinking, knowing, and understanding; Affection is reflected by verbs of liking, hating, loving, and fearing; and Perception contains verbs of seeing and hearing.

4- Relational Processes are called the processes of being, which can be realized by the verb "be" and other copular verbs like seem, appear, become, and verbs as own, possess and have. Relational processes involve two participants: Carrier and Attribute. Carrier refers to the entity which carries the attribute, while attribute refers to that which qualifies the entity. They can be subcategorized into three categories: Intensive, Possessive, circumstantial.

Table 7. Classifications and frequencies of verbalization processes

\begin{tabular}{|l|l|l|}
\hline Process & Sayer & Verbiage \\
\hline blaming (2) & All & Theirs \\
\hline lied (6) & & about you \\
\hline spoken (13) & You & the truth \\
\hline Total: 3 & 2 & \\
\hline
\end{tabular}

Table 8. Classifications and frequencies of mental Cognition process

\begin{tabular}{|l|l|l|l|}
\hline Verb (line No.) & Subcategory & Sensor & Phenomenon \\
\hline trust (3) & reaction & you & Yourself \\
\hline doubt(3) & reaction & you & You \\
\hline hated(7) & reaction & you & all \\
\hline look (8) & perception & you & too good \\
\hline dearm(9) & Cognition & you & \\
\hline think(10) & Cognition & you & \\
\hline bear (13) & Reaction & you & to hear the truth \\
\hline hear(13) & Perception & you & the truth \\
\hline hurt (27) & Reaction & you & \\
\hline Total: 9 & $\begin{array}{l}5 \text { reaction/ 2 perception } \\
\text { 2 cognition }\end{array}$ & 9 you & \\
& & & \\
\hline
\end{tabular}

Table 9. Classifications and frequencies of relational processes

\begin{tabular}{|l|l|l|l|}
\hline Verb (line No.) & Subcategory & Carrier & Attribute \\
\hline is (31) & & Yours & the earth \\
\hline be(32) & & You & Man \\
\hline Total $: 2$ & & & \\
\hline
\end{tabular}


The participants' prominent roles are Actor and Goal, and whether the process is controlled and done towards the goal. According to the transitivity model, the statistical outcomes of the data classification show that the most used actions are of intentionality subcategories $(93,10 \%)$. "You" is significantly involved as an actor (70\%) in the material processes. "you" is his son who is directed towards the goal which controls the actions. Besides, "You" is involved in a high percentage (24\%) as a sensor in the mental cognition process. The poem reflects instructions that tell how to be a good human being by adopting certain behaviors. The poem is devoted to "you," addressing his son directly and human being indirectly. "YOU" has to accomplish all the conditions and requirements that the poet states through the use of intentional material action processes along with the mental processes and through which the actor is directed towards the mentioned goal. Moreover, the poet uses these kinds of verbs to encode the reality in such a way that it seems that he reflects his experience of the world around in order to deliver a lesson to"YOU". Thus, it is manifested that actions that are considered conditions to be successful a good human being have to be accomplished intentionally by the actor or the doer of the action or what the poet called "You."

\section{Negating}

To enhance the aimed ideology, the poet uses negation to build a non- existing world in the mind of "you" in such a way that helps to create specific desire, fear, or belief. It can be achieved by using sets of triggers. Thus, negating a clause is gained through the use of negative particles, whereas negating a word is achieved through morphological, semantic, and pragmatic processes

Table 10. Types of negative forms

\begin{tabular}{|l|l|l|l|}
\hline Syntactically & Pronoun & Morphologically & Lexically \\
\hline not be (5) & nothing(23) & unforgiving(29) & lose(2) \\
\hline don't deal(6) & none(28) & & hated(7) \\
\hline don't give(7) & & & broken(15) \\
\hline don't look(8) & & & lose(19) \\
\hline not make(9) & & & hurt(27) \\
\hline not make (10) & & & never (6) \\
\hline nor lose(26) & & & \\
\hline Neither for.... nor loving(27) & & & \\
\hline
\end{tabular}

The poem is full of negative sentences in the main conditional clause in form of order. The poet delivers his didactic message in a very negative manner. All instructions are devoted to things that one doesn't have to do, or it is better not to do or never do, to achieve a successful life instead of giving positive instructions. The poet makes "You" fears to do these forbidden things or behaviors. He makes him imagine the other reality that stands behind the negative action. Negating is used to denote a mental activity more significant than the direct negation of a verb. This concerns its pragmatic force, which is used to render the addressee "You" conscious of situations that occurs if the opposite happens. The importance of the textual practice of negation in this poem makes the addressee built a virtual version of reality even though it is imaginary. Besides, it let the reader imagine the hypothetical situation to the degree that it may have a persuasive power, which should be positive according to this poem. 


\section{Conclusion}

'Stylistic tools are used to show that the poem recalls actions, and the emphasis is put on the "You" to refer to ALL. The poet uses certain stylistic elements to reach his intended semantic goal and affect the reader. The poet uses the content words relying mainly on the nouns and verbs with no adverb just to reflect that these instructions are not for the time being. They are set for all times. Besides, the poet uses particular poetic foregrounding such as repetition, especially when repeated the words If and "you" several times with parallelism and deviation just to direct the reader to the conditions that imply the instructions and recognize the gift that the reader may get if he/she fulfill these conditions.

Critical stylistic devices steer the text in such a way that let the writer or producer reaches the set goal. The use of transitivity to promote the ideational function in the text. The poet uses two kinds of lexical verbs (intentional material action and mental process) significantly. The poet succeeded in setting his embedded ideology through this choice. He used these verbs to make "You" the addressee realized that he/she should follow and do all the mentioned guidelines to have a good life even though they are not compulsory. The port makes the addressee realize and imagine the other world that he/she might have through the use of negation. The poet uses the mentioned tools in a very clever way that leads All not only his son "You" to follow and consider it a moral lesson of life.

\section{About the Authors;}

Suadad Fadhil Kadhum holds a Master of Arts degree in English Language and Linguistics from the University of Baghdad, College of Languages. I am an Assistant Professor in the department of English at the College of Languages, and I have been teaching at the university since 1999. I published several papers concerning my major. My research interest is discourse, pragmatics, stylistics, and cognitive issues.

https://orcid.org/0000-0002-1600-057X

Nawar Hussein Al-Marsumi is an Assistant Professor, holding the Master of Arts degree in English Language and Linguistics obtained from the University of Baghdad, College of Education- Ibn Rushd. Since 1999, I have been working at Baghdad University as a teaching member in the Department of English. My major is the English language and linguistics, and I published several papers in contrastive studies, stylistics and pragmatics.

https://orcid.org/0000-0002-3918-5984

\section{References}

Abrams, M. H. [ed.] (1999). A Glossary of Litrary Terms ( $7^{\text {th }}$ ed.). Boston: Heinle \& Heinle. Coffey, L. (2013). Innocent Until Proven Filthy: A Corpus-Based Critical Stylistic Analysis of Representation of Men in Women's Magazines, (Unpublished PhD Thesis). The university of Huddersfield,UK .

Dorpar, M. (2015 ). The Arguable Stylistic Layers in Critical Stylistics of Short Story and Novel. Language Related Research, 5(5), 65-94.

Eggins, S. (2004). An Introduction to Semantic Functional Linguistics (2 ${ }^{\text {nd }}$ ed.). New York: Continuum International Group.

Evans, M., \& Schuller, S. (2015). "Representing "terrorism": The Radicalization of the May 2013 Woolwich Attack in British Press Reportage. Journal of Language Aggression and 
Arab World English Journal (AWEJ) Volume 12. Number 1. March 2021

Conflict, 3(1), 128-150

Fairclough, N. (1989). Language and Power. New York: Longman.

Fowler, R. (1991). Language in the News: Discourse and Ideology in the Press. London and New York: Routledge.

Halliday, M . A. K. (1985) An introduction to functional grammar .London: Arnold.

Halliday, M. (1994). An Introduction to Functional Grammar (3 ${ }^{\text {rd }}$ ed.). London: Edward Arnold.

Haynes,J. (2006) Style. London: Routledge.

Jeffries, L. (2010). Critical Stylistics: The Power of English. New York: Palgrave Macmillan. Jeffries, L. (2016). Critical Stylistics". In S. Violeta. (ed.), The Bloomsbury Companion to Stylistics (pp. 157-175). London: Bloomsbury.

Kipling, R. (1943). If. Retrieved from:<http://www.poetryfoundation.org/poem/175772>

McIntyre D (2010) The year's work in stylistics 2009. Language and Literature 19(4): 396411.

Norgaard, N., Busse, B., \& Montoro, R. (2010). Key Terms in Stylistics. London: Continuum International Publication Group.

Olaluwoye, L.(2015) . "A Critical Stylistic Analysis of the Identity Minority Groups in the Nigerian Print Media". Journal of Literature, Language and Linguistics 16, 87-93.

Scott, J. (2013). Creative Writing and Stylistics: Creative and Critical Approaches. Basingstoke: Palgrave Macmillan.

Simpson, P. (2004). Stylistics. London: Routledge.

Simpson, P. (1993). Language, Ideology and Point of View. London and New York: Routledge.

Spencer, A. (1998). Paul's Literary Style. New York: University Press of America. Verdonk, P. (2002). Stylistics. Oxford: Oxford University Press.

\section{Appendices}

Appendix A

Table 6. Classifications and frequencies of material action processes

\begin{tabular}{|l|l|l|l|}
\hline Verb (line No.) & Subcategory & Actor & Goal \\
\hline keep (1) & Intention & You & your head \\
\hline losing (2) & Intention & All & Theirs \\
\hline make allowance(4) & Intention & You & their doubt \\
\hline wait (5) & Intention & You & \\
\hline give(7) & Intention & You & Way \\
\hline talk(8) & Intention & You & Wise \\
\hline meet (11) & Intention & You & triumph and disaster \\
\hline treat(12) & Intention & You & those impostors \\
\hline twisted (14) & Event & Knaves & You \\
\hline watch (15) & Intention & You & Things \\
\hline gave( 15$)$ & Intention & You & your life \\
\hline broken(15) & Intention & You & Things \\
\hline stoop(16) & Intention & You & Things \\
\hline
\end{tabular}


Arab World English Journal (AWEJ) Volume 12. Number 1. March 2021

Al-Janabi \& Al-Marsumi

\begin{tabular}{|l|l|l|l|}
\hline build up(16) & Intention & You & Things \\
\hline make(17) & Intention & You & Heap \\
\hline risk (18) & Intention & You & your winnings \\
\hline lose(19) & Intention & You & your winnings \\
\hline start (19) & Intention & You & \\
\hline breathe (20) & Intention & You & a word \\
\hline serve (22) & Intention & You & your turn \\
\hline gone(22) & Event & heart and nerve and sinew \\
\hline hold on (23) & Intention & You & \\
\hline says (24) & Intention & Will & Them \\
\hline hold on (24) & Intention & Will & Them \\
\hline talk(25) & Intention & You & Crowd \\
\hline walk(26) & Intention & You & King \\
\hline lose (26) & Intention & You & common touch \\
\hline count(28) & Intention & all men & You \\
\hline fill(29) & Intention & You & unforgiving minutes \\
\hline Total: 29 & 27 intention & $\begin{array}{l}23 \text { you } \\
6 \text { variable }\end{array}$ & \\
\hline
\end{tabular}

If by Rudyard Kipling

\section{Appendix B}

IF you can keep your head when all about you

Are losing theirs and blaming it on you,

If you can trust yourself when all men doubt you,

But make allowance for their doubting too;

If you can wait and not be tired by waiting,

Or being lied about, don't deal in lies,

Or being hated, don't give way to hating,

8 And yet don't look too good, nor talk too

wise:

if you can dream - and not make dreams

your master;

If you can think - and not make thoughts your aim;

If you can meet with Triumph and Disaster And treat those two impostors just the same; If you can bear to hear the truth you've spoken

Twisted by knaves to make a trap for fools,
Or watch the things you gave your life to, broken,

And stoop and build 'em up with worn-out tools: If you can make one heap of all your winnings And risk it on one turn of pitch-and-toss, And lose, and start again at your beginnings And never breathe a word about your loss; If you can force your heart and nerve and sinew To serve your turn long after they are gone, And so hold on when there is nothing in you Except the Will which says to them: 'Hold on!' If you can talk with crowds and keep your virtue,

' Or walk with Kings - nor lose the common touch,

if neither foes nor loving friends can hurt you, If all men count with you, but none too much; If you can fill the unforgiving minute With sixty seconds' worth of distance run, Yours is the Earth and everything that's in it, And — which is more - you'll be a Man, my son! 